\title{
A Review of Teaching and Learning Linguistic Politeness
}

\author{
Leei Wong (Corresponding author) \\ Sheridan Institute of Higher Education, Western Australia \\ Email: Leei.Sung@alumni.anu.edu.au \\ Joshua Esler \\ Sheridan Institute of Higher Education, Western Australia
}

Received: 19/08/2020

Accepted: 05/10/2020

Published: 01/11/2020

Volume: 1 Issue: 4

How to cite this paper: Wong, L., \& Esler, J. (2020). A Review of Teaching and Learning

Linguistic Politeness. Journal of Critical Studies in Language and Literature, 1(4), 13-21

DOI: https://doi.org/10.46809/jcsll.v1i4.38

Copyright $(0) 2020$ by author(s) and Global Talent Academy Ltd. This work is licensed under the Creative Commons Attribution International License (CC BY 4.0).

http://creativecommons.org/licenses/by/4.0/

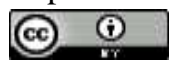

\begin{abstract}
Research on politeness has flourished since Brown and Levinson's (hereafter B\&L) classical (1978, 1987) definition of politeness theory, and has extended to current research on impoliteness. However, there is a knowledge gap in the area of Teaching and Learning Politeness (hereafter TLP) in second language acquisition.This paper aims to identify this gap, by tracing the roots of research on TLP since 1975, to explore how past research has impacted current trends, and then focuses on the position and relevance of TLP in the local Australian curriculum, in the area of intercultural competency, benchmarked in reference to the Common European Framework of Reference (CEFR). The synthesis of the literature in this paper will elicit the challenges in TLP and potentially result in a clearer direction in the area of second-language research on politeness.
\end{abstract}

Keywords: Politeness Theory, Teaching and Learning Linguistic Politeness, Second Language Acquisition

\section{Introduction}

Politeness is commonly defined as the necessary means to maintain good social, interpersonal relationships and is vital for everyday communication (Liu, Volčič Zala, \& Gallois, 2019) in an intercultural context. While this commonly recognized definition is straightforward, the research on politeness is diverse, ranging from sociolinguistics to psychology. The nature of politeness is complex, and, while language educators look for grammatical competence and communicative competence, there is no 'politeness competence' that can be measured objectively, as different individuals may have different conceptualizations of politeness (Mills,2003; Dewaele,2008; Taavitsainen, Jucker, \& Schneider, 2012; Pizziconi, 2015), and may have different reactions to the same behaviour in a given situation.

In the last two decades, politeness research has shifted toward a focus on impoliteness (impoliteness output strategies to determine traits of impoliteness), beginning with scholars such as Culpeper (1996), and later Bousfild and Locher (2008); Kecskes (2015); Culpeper, Haugh \& Kádár (2017); and Huang and Brown (2017). Culpeper (2005) adopts Tracy and Tracy's (1998) definition of impoliteness as the intentional offensive act of speakers "perceived by members of a social community" (Tracy and Tracy, 1998, p.227). Kecskes (2015) thinks this definition is especially appropriate in the intercultural setting because it is the conceptualization of impoliteness according to the common norms of communication even between different intercultural social groups. Research has also been dominated by the discursive approach since Eelen (2001) proposed a model of politeness with three central tenets: argumentativity, historicity and discursiveness (Kecskés, 2014). However, the 
main concern within scholarship that is critical of this approach is that the discursive turn in (im)politeness research is nonpredictive. The discursive approach is highly varied and does not provide "a global model for the analysis of politeness" (Mills, 2017, p. 15). B\&L's (1987) classical politeness theory may therefore still provide insights where contemporary research on (im)politeness falls short.

Politeness is one of the most researched areas in contemporary pragmatics (OKeeffe, Clancy, \& Adolphs, 2012). However, "Pragmatic manuals too seem to encourage a decontextualized understanding of matters of politeness" (Bella, Sifianou \&Tzanne, 2015, p. 84) and "much less work has focused on the teaching aspect" (Pizziconi and Locher, 2015, p.3). Pizziconi and Locher (2015) list some of the inadequacies or one-sided approaches in politeness research circles such as Bou Franch and Garcés-Conejos Blitvich's (2003) confined theoretical approach. Other examples are Matsumoto and Okamoto's (2003) as well as Brown's (2010) limited approach to reviews of instructional material. Some empirical studies have been conducted by scholars such as Ishida (2009) and Tateyama (2009) on metapragmatic awareness, but these are still incomplete.

The publication of the first book on teaching linguistic politeness in 2015 by Bella and Tzanne is a welcomed effort in this limited research area. It shows that scholars have begun to focus on TLP as a vital area of research. The authors emphasize that linguistic politeness must be explicitly taught because "unlike native speakers who may be socialized into politeness in their native language, learners of foreign languages will have to learn how to behave politely" (Bella, Sifianou \& Tzanne, 2015, p. 23). Despite the need for a more comprehensive approach to teaching politeness in language classrooms, the authors summarise the lack of research on TLP in present language education, despite the growth of research on politeness:

Despite the tremendous expansion of research on politeness over the last thirty-five years and impoliteness more recently, comparatively little has been done on the teaching of politeness. This state of affairs raises several issues including the possibility and the ways of teaching politeness. (Bella, Sifianou \& Tzanne, 2015 , p. 23).

There are several reasons for the lack of teaching politeness in language classrooms, and also research on TLP. In the area of teaching and learning Chinese language, Lu (2015) attributes the lack of research on TLP to how politeness is taught in language classrooms, identifying three main factors. Firstly, the avoidance of teaching politeness in the Chinese classroom is due to inadequacies in the teachers' pragmatic knowledge. Secondly, common misuses of politeness strategies in second language learners is prevalent but is mostly ignored by educators. Thirdly, the over-emphasis on grammar and vocabulary in most instructional resources overshadows the need to teach politeness language usage. Bardovi-Harlig (2017) identifies similar ongoing challenges in the area of Instructed Second Language Acquisition (ISLA), such as "lack of authentic pragmatic input in teaching materials" (Bardovi-Harlig, 2017, p. 228) and "lack of instructor knowledge" (Bardovi-Harlig, 2017, p. 228). In addition to Lu's (2015) and Bardovi-Harlig's (2017) observations, another important aspect that is often overlooked is that many language educators and researchers are native speakers, for whom politeness conventions may be 'transparent'. That is, native language teachers are often unaware of the intricacies in the knowledge of the language, and how second language learners require explicit instruction on aspects that seem obvious to native teachers. They would thus tend to rely on the resources available to them. For instance, Economidou-Kogetsidis (2015) advocates the need for explicit email instruction in English as a Foreign / Second Language as a means of effective pedagogical intervention.

Research has shown that the problems outlined in the area of TLP have still not been sufficiently addressed. The challenges are undeniable; LoCastro (1997), for example, observes the lack of 'politeness competence' in Japanese learners and speakers of English, and Bella and Tzanne's research articulates the difficulty in identifying methods to determine linguistic competency in the area of politeness. Isosävi's (2020) study shows that non-native speakers reacting to different cultural politeness norms. The shortcomings of teaching politeness in language classrooms are of course, fuelled by the inadequacies of teaching resources for TLP, as outlined by Pichastor (1996), which are still prevalent in the present-day context. Ismail, Aladdin and Ramli (2014) quote Pichastor (1998) that, "the main concern in language textbooks is whether politeness strategies are presented in a manner to facilitate the understanding of the concept" (Pichastor,1996, p. 4). As mentioned above, regarding the lack of pragmatic knowledge among language educators (Bardovi-Harlig, 2017), teaching resources are an important guideline that direct the teacher's practice. An example is provided in Ismail, Alladin, and Ramli's research on English and Spanish language textbooks; the authors outline in their findings the lack of explanation in the textbooks regarding politeness usage and the absence of politeness strategies presented contextually.

\section{Evolving research on TLP and Australian and European Frameworks of Reference}

Having examined some of the background challenges in TLP, it is essential to look at how the field has evolved and to trace subsequent attempts at resolving these challenges. Some scholars have adopted B\&L's politeness theory, and some have modified the theory to suit pedagogies in the classroom. Gomes de Matos' research in 1975 is an early attempt to address the topic of teaching and learning politeness. Her paper' politeness Pays' highlights the 'Think and Choose an Opening' section on polite English dialogue in an EFL (English as a foreign language) textbook and the applicability for teaching linguistic politeness in the classroom. The instructions in the textbook demonstrate to teachers the steps in guiding students to select the most polite, next polite and least polite dialogue sentences to use in specific situations. Gomes de Matos' (1975) paper also draws attention to the teacher's manual with the addition of two sample questions as well as subsequent guidance for 
teachers. Gomes de Matos' (1975) work is essential, as there is evidence that there have been early attempts among writers of textbooks and teacher's manuals to highlight the importance of teaching linguistic politeness. The presentation of the resources is adequate and precise, and it serves as a valuable reference for language teachers and textbook writers.

There was a long gap in research on TLP since Gomes de Matos' (1975) work, until Pichastor's 1996 study, the latter of which adopts a general framework of communication, using Sperber and Wilson's $(1986,1995,2011)$ principle of relevance - the effective strategies employed by the addressee, and situational, cultural and contextual differences. At the same time, Pichastor (1996) states the inter-relatedness between the politeness principle (Grice 1975; Leech 1983; Brown \& Levinson, 1987) and the principle of relevance in the understanding of politeness strategies. The importance of the study lies in the incorporation of politeness theories and the emphasis on Fraser's (1990) 'appropriateness' in a conversation, taking into account the various factors in a conversational discourse such as power and status, as well as cultural factors.

Pichastor's (1996) study is the first to focus on "appropriateness" in politeness-teaching and learning and may have influenced future scholars, given their similar emphasis on 'appropriateness' in the area of teaching and learning politeness. One example is Meier (1997) "Teaching the universals of politeness?" where Meier proposes "Politeness as appropriateness" (p.24), and continues "I propose that the most useful working definition of politeness for second /foreign language pedagogy is that of appropriateness." (Meier, 1997, p. 24).

Other recent examples of scholars engaging the term 'appropriateness' include Bou-Franch (2003), Bella, Sifianou and Tzanne (2015) and Savic (2018). Meier's suggestion to replace the term 'politeness' with 'appropriateness' is also shared by Bou-Franch \& Garces-Conejos (2003), but Meier (1997) differs from the latter in her view on B\&L's politeness theory. Meier (1997) articulates the problems in Brown and Levinson's (1987) politeness theory. First of all, the notion of politeness is not well-defined. However, Levinson (1983) has previously admitted that pragmatics is a notion that is hard to determine (Grant, 2011) and until the present day, there is still no common consensus on the definition of politeness. Meier (1997) also highlights the problems in Brown and Levinson's definition of positive and negative face-wants across cultures, as mentioned by other scholars such as Matsumoto (1988). Another problem is the universality of indirect speech acts across cultures as articulated by House and Kasper (1981). However, Bou-Franch \& Garces-Conejos' (2003) methodological proposal for teaching linguistic politeness, on the other hand, does not concur with Meier's views on the B\&L model, stating that the classic theory is still relevant from a socio-cognitive perspective on the use of language (p.6). Bella, Sifianou and Tzanne (2015) do not refute the usefulness in the adoption of the term 'appropriateness'. Instead, they argue that the change from the term 'politeness' to 'appropriateness' could result in more confusion, as, citing Culpeper (2011), 'appropriateness' denotes a broader spectrum of meaning than politeness. For example, inappropriate speech does not always equate to impolite speech. Furthermore, they caution that it is not solely the "avoidance of inappropriateness" (Bella, Sifianou \& Tzanne's, 2015, p. 30) that defines 'appropriateness' in TLP, just as the notion of politeness is not precisely the opposite of impoliteness. For example, impoliteness is mostly expressed verbally in the Greek culture, but politeness usually expressed in non-verbal action (Sifianou \& Tzanne, 2010).

Although there is a difference in how scholars define politeness, Meier's study can be considered the first complete work on teaching politeness (in the context of teaching Spanish as a second language). She proposes three groups of cultural awareness-raising activities, which address "causes of pragmatic failure and negative transfer" (p. 26) due to learners' interference of their mother tongues - for instance, adapting textbook conversations to raise learners' awareness on the various social settings and contexts.

Besides discussion concerning 'appropriateness', and Meier's valuable study employing this term in her investigation of the teaching of politeness, B\&L's politeness theory continues to be at the centre of ongoing discussions. Although there has been much debate on the universality of the theory and Anglo-Saxon perspectives over the last 40 years, it is still considered by many scholars to be the "most significant" theory in this field (Eelen, 2001: p. 3; Leech, 2005: p. 1; LoCastro, 2012, p. 137) due to its well-structured model. In the area of TLP, B\&L's politeness theory plays an important role, although scholars share different views. The discursive approach in politeness research, as outlined in Eelen (2001), has added new insights to the area of TLP, which are as valuable as B\&L's findings (Pizziconi and Locher, 2015). However, the discursive approach to the prominent politeness and impoliteness research in the Western academic scene has been criticized in recent years by scholars such as Kecskés (2014), Haugh (2008), and Kádár (2009). Their main concern, as mentioned earlier, is that the discursive turn leans towards a non-predictive approach, and thus B\&L's politeness theory still holds prominence due to its more structured approach. Further research into both approaches could further expand the field of TLP.

Apart from a focus on 'appropriateness' and B\&L's (1987) politeness theory, speech acts have been another area for investigation among researchers in the area of TLP. For example, Shih's 1999 work on Chinese politeness (the first study of its kind) examines a cross-cultural study of conversational politeness in Chinese and English as a foreign language, in the context of conversational politeness and foreign language teaching. The study makes a systematic comparison of politeness rules and strategies used in the Chinese and English language. Although the study does not explicitly outline methodological steps in its analysis, its exploration of the linguistic strategies commonly used for politeness, and cases of polite language usage (forms of address, compliment responses, greetings, and requests and rejections) suggests important implications for the teaching of politeness in the Chinese and English foreign language classrooms. The area of speech acts in politenessstudies is still an important field for investigation among current scholars, as touched upon later in this paper. 


\section{Communicating, Socialising}

4.9 identifying levels of politeness, respect and formality likely to influence the effectiveness of interactions across languages in diverse contexts, for example seeking assistance, engaging with people of different ages or authority. -- making a judgment on how to address and refer to others, for example, whether to address a stranger as jiejie (older sister) or ayi (auntie) in Chinese and how they would be addressed in English

8.2 Plan and arrange multicultural projects and events with peers that would benefit their school and local community [Key concepts: politeness, respect, compromise]

-indicating agreement and disagreement in polite ways and expressing gratitude for time and services provided

10.1 participating in discussions and expressing personal opinions on issues relevant to contemporary youth, displaying levels of politeness or assertiveness as appropriate to the context,

10.2- discussing issues, suggesting alternative solutions and making decisions using levels of formality and respect appropriate to audience and purpose,

-Plan and negotiate actions to contribute to their local and global community and suggest alternatives in -interactions with local organizations [Key concepts: politeness, proactivity/initiative]

- displaying respect for ideas of others in interactions, agreeing to disagree, or negotiating to achieve agreement,

\section{Socialising, Translating}

8.8.- Identify how contextual cues in Chinese texts and interactions assist with understanding and apply this knowledge in simple translations [Key concepts: politeness symbols, linguistic landscape]

-interpreting key ideas from Chinese to English with explanation of the contexts and customary way of using fixed phrases, for example, discussing what Chinese parents would say to their child when dropping them off at school as the Chinese version of 'Have a good day'; what is the English version of jiayou; and why people say jiayou at a Chinese sports event.

- interpreting interactions in Chinese between peers or in texts (for example, viewing a segment of a movie), including both the meaning of the dialogue as well as comparing culturally determined manners or behaviour.

- using etiquette phrases within an appropriate context and discussing whether the translation of 'sorry' should be the same in context, 'duibuqi ' rangyirang' and 'duibuqi ' wocuole.'

\section{Years 7 and 8 Achievement Standard}

-... In class discussions in English, they recognize and describe diversity within the Chinese spoken and written language and express their own understandings of Chinese cultural values which influence and are reflected in everyday communication, for example, respect, politeness and the importance of family.

\section{Understanding/Systems of language/ Reflecting}

10.11 identifying and responding to intended and unintended meanings reflected in interactions, for example, noticing contradictions between what is being said and the posture, movement, gesture and expression of participants ('How do I seem interested when I am not?', 'How do I interpret participants' real meaning?', 'Are they just being polite or are their words genuine?')

10.14 analyzing features of texts in formal domains, for example in articles: including titles, placement of author, organization into introduction, body and conclusion; in formal letters: making a comparison with aspects of personal letters such as salutations, politeness.

Pizziconi and Locher (2015) also mention the importance of the intercultural aspect in teaching politeness, citing $\mathrm{O}^{\prime}$ Keeffe's, Clancy's and Adolph's (2011) exercises and tasks for learning English as formulaic and lacking in intracultural perceptions of (im)politeness and contextual information. However,

O'Keeffe's, Clancy's and Adolph's (2011) proposed way of teaching positive politeness, negative politeness, and other politeness markers are based on Brown and Levinson's politeness theory. The intercultural aspect of teaching politeness could be applied using the approach as a springboard. Indeed, the significance of Intercultural Communicative Competence is emphasized in the curricula for language teaching in Australia, with politeness listed as one of the goals under the category of Intercultural Communicative Competence. Intercultural understanding is, however, a "relatively recent addition to Australian school curriculums" (SCSA, 2018), and therefore the exact nature of its place in TLP is still being formulated. Intercultural understanding capability is defined against the definition of culture outlined in the article' Shape of the Australian Curriculum: Languages' (ACARA, 2011) as involving: "a complex system of concepts, values, norms, beliefs and practices that are shared, created and contested by people who make up a cultural group and are passed on from generation to generation. Cultural systems include various ways of seeing, interpreting and understanding the world. They are constructed and transmitted by members of the group through the processes of socialization and representation" (ACARA, 2011, p. 16). Moreover, in the same article, intercultural understanding is defined according to Scarino, Dellitt and Vale (2007) as: "...assum[ing] an integral connection between language and culture, acknowledging language as the primary means through which people establish and exchange shared meaning and ways of seeing the world" (ACARA, 2011, p.16). Based on this definition, intercultural understanding as taught in the Australian curriculum focuses on sharing, creating and contesting 
different cultural perceptions and practices, and supports the development of a critical awareness of the processes of socialization and representation that shape and maintain cultural differences.

In line with this definition, below is an example of a table outlining the skills that are required in the area of politeness under the heading of Intercultural Communicative Competence, adapted from the Australian Curriculum: Languages Chinese (revised), Chinese for L2 Foundation to Year 10 Sequence, published in 2013.

Table1. Adapted from "The Australian Curriculum: Languages Chinese (revised), Chinese for L2 Foundation to Year 10 Sequence," $\quad$ ACARA, $2013 \quad$ (http://docs.acara.edu.au/resources/F-10_Australian_Curriculum_Languages__revised_Chinese_-_Nov_2013.pdf 2013).

Similarly, according to a commonly referenced benchmark for teaching and learning second languages - the Common European Framework of Reference (CEFR) for language skills assessment (Council of Europe, 2001) - politeness conventions are classified as one of the essential aspects of teaching (Hyland \& Paltridge, 2011; Bella, Sifianou \& Tzanne, 2015). A 2018 update of the CEFR Companion Volume with New Descriptors classifies politeness as a B1 level descriptor (table below) on the scale of Politeness Conventions (p. 124).

Table 2: CEFR Companion Volume with New Descriptors (2018, p. 124).

ACTING AS INTERMEDIARYIN INFORMAL SITUATIONS (WITH FRIENDS AND COLLEAGUES)
C2 Can communicate in clear, fluent, well-structured (Language B) the sense of what is said in (Language A) on a wide range
of general and specialised topics, maintaining appropriate style and register, conveying finer shades of meaning and
elaborating on sociocultural implications.
Can communicate fluently in (Language B) the sense of what is said in (Language A) on a wide range of subjects of
personal, academic and professional interest, conveying significant information clearly and concisely as well as explaining
cultural references.
Can mediate (between Language A and Language B), conveying detailed information, drawing the attention of both sides
to background information and sociocultural cues, and posing clarification and follow-up questions or statements as
necessary.
Can communicate in (Language B) the sense of what is said in a welcome address, anecdote or presentation in hisher
field given in (Language A), interprefing cultural cues appropriately and giving additional explanations when necessary,
provided that the speaker stops frequently in order to allow time for himher to do so.
Can communicate in (Language B) the sense of what is said in (Language A) on subjects within hisher fields of interest,
conveying and when necessary explaining the significance of important statements and viewpoints, provided speakers give
clarifications if needed.
Can communicate in (Language B) the main sense of what is said in (Language A) on subjects within hisher fields of
interest, conveying straightorward factual information and explicit cultural references, provided that heishe can prepare
beforehand and that the speakers articulate clearly in everyday language.
Can communicate in (Language B) the main sense of what is said in (Language A) on subjects of personal interest, whilst
following important politeness conventions, provided that the speakers articulate dearly in standard language and that
helshe can ask for clarification and pause to plan how to express things.

The focus on additional language learners is essential, because what would be considered 'cultural norms' in a first language community would include some understood values around politeness, expressed through register or lexicon. However, additional language learners, on the other hand, bring their cultural backgrounds and semiotic experiences to language learning. These experiences are usually inculcated, with politeness practices arising from these language and cultural experiences. Students, therefore, need to be taught how to interrogate and encounter politeness in the language and culture from different perspectives. Kecskes (2014) emphasizes a similar point concerning intercultural impoliteness, noting that "impoliteness may work differently in intercultural interactions than in L1 communication" (p.43), and that "interlocutors may sometimes be unaware of impoliteness because it is conveyed implicitly or through paralinguistic means that function differently for speakers with different L1 backgrounds" (p.43). Diaz's (2013) languaculture (Agar, 1994) approach in looking at language and culture may similarly be integrated in the area of TLP. Her "interculturally aware vision" (p. 25) to "communicate confidently in culturally appropriate ways, in a variety of contexts and settings" (p. 24), and the empirical evidence outlined in Chapter 3 of her 2016 study, help to close the gap between language and culture pedagogy in language-teaching. This is achieved through her examination of the positive and negative outcomes of the pedagogic intervention paradigm, and the conceptual discussions, empirical accounts, and case studies outlined in both her 2013 and 2016 works.

\section{Teaching approaches and resources}

The brief exposition above on current research and teaching shows the emerging role of TLP in second-language acquisition. In the area of teaching approaches, scholars have suggested three main models in various second-language learning settings: an eclectic approach, a reflexive approach, and an interactional approach. The eclectic approach proposed by Bella, Sifianou and Tzanne (2015), with reference to B\&L's (1987) classic theory, equips teachers and learners with explicit, practical steps and activities in the teaching of Greek as a second language. Ramos-González and Rico-Martín 
(2015) propose a reflexive teaching approach (reflexivity) for teachers as a methodological guide in the teaching of Spanish as a foreign language, whereby the teachers practise to reflect upon and subsequently improve their teaching practice (Stîngu, 2012). Haugh and Chang (2015) propose an interactional approach (Haugh 2007; Haugh 2015; Kádár \& Haugh 2013) whereby learners learn through authentic interactional data as an effective way to raise the awareness of multiple understandings of im/politeness between learners' first and second language politeness systems.

Alongside these teaching approaches, scholars specifically propose the inclusion of a pedagogical framework for the teaching of (im)polite behaviour in the classroom, as outlined for example in Culpeper's and Haugh's 2017 guide, 'The Palgrave Handbook of Linguistic (Im)politeness'. Yoon \& Brown (2018) similarly present a contemporary multiliteracies paradigm to teaching Korean multimodal (im)politeness. Their approach highlights the importance of situating language use within socially complex multimodal contexts.

Apart from situating TLP within different teaching approaches and frameworks, the effectiveness of teaching resources in TLP is another area of research examined by TLP scholars. Nijakowska (2013) discusses linguistic politeness notions presented in English as a Foreign Language methodology textbooks. Babická and Nevařil (2016) investigate the presentation of politeness conventions in ten English coursebooks for advanced English learners and compare polite expressions and phrases against different social contexts. Specifically, concerning the Australian curriculum for teaching Chinese as a second language, inadequacies in teaching resources are revealed in the latest report commissioned by the Australia-China Relations Institute (ACRI) in 2016. It states that teaching resources "are not tailored to the Australian context and are often in contradiction to the principles of the Australian Curriculum for Languages." (ACRI, 2016). That is, current teaching resources focus on how one should speak, behave, and act exclusively within a localized Chinese setting, without taking into account the diversified settings outside of China (and in this case, specifically Australia) in which the Chinese language is used [examples comparing Chinese and Australian contexts]. Lu's (2017) investigation of three Chinese-as-a-foreignlanguage textbooks based on conversation models further strengthens arguments concerning the explicitly Chinese nature of Chinese language resources in general for foreigners, claiming that they demonstrate "inconsistency between linguistic proficiency and nativity" (p.66). Another example is Nodoushan's (2012) study, which highlights that textbook authors create straightforward conversation models intentionally focusing solely on grammar and usage instead of real-life conversations. There is a consensus, therefore, among TLP researchers, that language teaching resources often do not take into account the diverse cultural settings in which the target language is used, nor real-life models in which forms of politeness will be used.

Other teaching resources examined by scholars include authentic teaching resources such as television programmes and emails. Ramos-Gonzalez and Rico-Martin (2015) present a descriptive study of five television series broadcast on the Internet as a resource for the teaching of Spanish as a foreign language.

The teaching resources at the disposal of TLP educators are therefore diverse, yet require appropriate teacher input to realize their full potential in the teaching of politeness to second language learners, as Bou-Franch and Garces-Conejos' (2003) point out. Their study outlines methods that may still be applicable in the present-day context of teaching and learning linguistic politeness in that, besides highlighting the notion of "appropriateness" (p.7) and implementing "awareness-raising tasks" (p.7), lessons can be "complemented by pragmatic knowledge provided by the teacher (p.7)". The difference between Meier's (1997) proposal and that of Bou-Franch and Garces-Conejos (2003) is that the latter proposes the addition of the pragmatics component and advocate making politeness theory more contextually relevant. Bella, Sifianou and Tzanne (2015) also agree to the use of 'appropriateness' but disagree with Bou-Franch and Garces-Conejos (2003) in the use of the terms' positive politeness' and 'negative politeness' in B\&L's politeness theory, when teaching linguistic politeness in the classroom. Bella, Sifianou and Tzanne's (2015) proposal of teaching politeness can be seen as a further extension of Bou-Franch and Garces-Conejos' (2003) proposal, providing several suggestions for educators teaching different levels such as lowintermediate and the intermediate levels. The addition of explicit examples and activities also serve as useful recommendations for teachers. For instance, providing learners with authentic samples of telephone conversations learning about accepting and rejection in requests, through a series of discussion questions such as the interlocutors' relationship and the context of the conversation.

Recent studies on TLP, though limited, exhibit the emergence of this field across different genres in various second language settings and encourage further research by scholars and exploration by teachers.

\section{Conclusion}

Politeness is the necessary means to maintain good social, interpersonal relationships and is vital for everyday communication. Linguistic competence in the context of a complex, globalized environment presents new challenges for language educators. This paper has traced the roots of TLP in second language acquisition and examined its present state and challenges. TLP is an emerging area within the fields of second-language acquisition and politeness studies. Current scholarship on TLP focuses on traditional methods of examining speech acts; various teaching approaches; teaching frameworks and investigations into teaching resources.

To prepare learners for effective communication in international contexts, it is necessary to establish how politeness is expressed in modern language and investigate how politeness practices are best taught and learned. Specific examination of references to TLP in the Australian in the global context (the latter measured against the CEFR) points to a clearer direction for further development of TLP in the area of second-language acquisition. 


\section{References}

Adolphs, S., Semlyen, L., Clancy, B., \& OKeeffe, A. (2011). Introducing Pragmatics in Use. Routledge.

Australian Curriculum, Assessment and Reporting Authority (ACARA). (2011). National Report on Schooling in Australia 2011. Retrieved from https://www.acara.edu.au/

Australian Curriculum, Assessment and Reporting Authority (ACARA) (2013). Australian Curriculum: Languages Chinese (revised), Chinese for L2 Foundation to Year 10 Sequence. Retrieved October 29, 2019, from https://docs.acara.edu.au/resources/F-0_Australian_Curriculum_Languages_-_revised_Chinese_Nov_2013.pdf

Australian Curriculum, Assessment and Reporting Authority (ACARA) (2018). Work sample portfolios for Chinese. Retrieved from https://www.acara.edu.au/news-and-media/acara-update-archive/acara-update- archive-2018/acaraupdate-december-2018.

Australian Federation of Modern Language Teachers Associations (AFMLTA), no date. Retrieved from www.afmlta.asn.au

Babicka, B. \& Nevaril, J. (2016). Learning politeness in a foreign language - the case of speaking activities in English coursebooks at the advanced level. Hradec Králové, Journal of Anglophone Studies, 3(1), 92-102.

Bardovi-Harlig, K. (2017). Acquisition of L2 pragmatics. In The Routledge Handbook of Instructed Second Language Acquisition (pp. 224-246). Taylor \& Francis.

Bella, S., Sifianou, M., \& Tzanne, A. (2015). 2. Teaching politeness? Teaching and Learning (Im)Politeness. Walter de Gruyter. doi:10.1515/9781501501654-003

Bou-Franch, P., \& Garcés-Conejos, P. (2003). Teaching linguistic politeness: A methodological proposal. IRAL, International Review of Applied Linguistics in Language Teaching, 41(1), 1-22.

Bousfield, D., \& Locher, M. A. (2008). Impoliteness in Language: Studies on Its Interplay with Power in Theory and Practice. Berlin: Mouton de Gruyter.

Brown, P., \& Levinson, S. (1978). In E. Goody (Ed.), Questions and Politeness: Strategies in Social Interaction, (pp. 56310). Cambridge: Cambridge University Press.

Brown, P., \& Levinson, S. (1987). Politeness: Some Universals in Language Usage (Studies in interactional sociolinguistics 4). Cambridge: Cambridge University Press.

Chen, X. (2017). Politeness phenomena across Chinese genres. Equinox Publishing. Confucius says. (2014, September 13). Retrieved May 6, 2019, from https://www.economist.com/news/china/21616988-decade- ago-china-began-openingcentres-abroad-promote-its-culture-some-people-are-pushing

Council of Europe (2001). Common European Framework of Reference for Languages: Learning, Teaching, Assessment. Cambridge: Cambridge University Press.

Council of Europe (2018). Companion Volume with new descriptors. Retrieved from https://rm.coe.int/cefr-companionvolume-with-new-descriptors-2018/1680787989.

Culpeper, J. (1996). Towards an Anatomy of Impoliteness. Journal of Pragmatics, 25(3), 349-367.

Culpeper, J. (2010). Conventionalized impoliteness formulae. Journal of Pragmatics, 42(12), 3232-3245. doi: 10.1016/j.pragma.2010.05.007

Culpeper, J., Haugh, M., \& Kádár, D. Z. (2017). The Palgrave handbook of linguistic (im) Politeness. London: Palgrave Macmillan.

Díaz, Adriana Raquel (2013). Developing Critical Languaculture Pedagogies in Higher Education: Theory and Practice. Retrieved from http://www.eblib.com

Diaz, A. R. (2016). Developing critical languaculture pedagogies in higher education: Theory and practice = Zai gao deng jiao yu jie duan fa zhan pi pan xing yu yan wen hua jiao xue fa: Li lun yu shi jian. Bristol: Multilingual Matters.

Eelen, G. (2001). Politeness and ideology. Ideologies of politeness Pragmatics. Quarterly Publication of the International Pragmatics Association (IPrA) Pragmatics, 9(1), 163-173.doi:10.1075/prag.9.1.09eel

Fraser, B. (1990). Perspectives on politeness. Journal of Pragmatics, 14(2), 219-236. doi: 10.1016/0378-2166(90)90081-n

Gomes de Matos, F. \& Instituto de Idiomas Yazigi, Sao Paulo (Brazil). Centro de Linguistica Grant, Lynn. Introducing pragmatics in use [Book Review] [online]. New Zealand Studies in Applied Linguistics, Vol. 17, No. 2, 2011: 128130.Availability: <https://search-informit-comau.ezproxy.une.edu.au/documentSummary; dn=808964375104236;res=IELHSS > ISSN: 1173-5562. [cited 08 Apr 20].

Grice, H.P. (1975). Logic and conversation. In Cole, P. \& Morgan, J.L. (Eds.) Syntax and Semantics, Vol 3: Speech Acts. New York Academic Press.

Gu, Y. (1990). Politeness phenomena in modern Chinese. Journal of Pragmatics, 14, 237-57.

Gu, Y. (2011). Modern Chinese politeness revisited. Politeness Across Cultures, 128-148. doi: 10.1057/9780230305939_7

Haugh, M. (2007). The discursive challenge to politeness research: An interactional alternative. Journal of Politeness Research. Language, Behaviour, Culture, 3(2). doi: 10.1515/pr.2007.013

Haugh, M. and Chang, W. (2015). Understanding im/politeness across cultures: and interactional approach to raising sociopragmatic awareness. IRAL: International Review of Applied Linguistics in Language Teaching, 53 (4), $389-$ 414.

Haugh, M., \& Kádár, D. Z. (2017). Intercultural (Im)politeness. In J. Culpeper, M. Haugh, \& Kádár, D. Z. 
House, J. and Kasper, G. (1981). Politeness markers in English and German. In Coulmas, F.(Ed.), Conversational routine. The Hague: Mouton.

Hubbert, J. (2020). China In The World: an anthropology of Confucius Institutes, soft power, and globalization. S.l.: Univ of Hawaii Press.

Hutheifa, Y. (2016). A Critical Review of Prominent Theories of Politeness. Advances in Language and Literary Studies, 7(6). doi:10.7575/aiac.alls.v.7n.6p.262

Hyland, K., \& Paltridge, B. (2011). Continuum companion to discourse analysis. London:Continuum.

Ismail, I. R., Aladdin, A., \& Ramli, S. (2014). Vous ou tu? : Towards understanding the politeness concept in French. Procedia - Social and Behavioral Sciences, 118, 184-189. doi:10.1016/j.sbspro.2014.02.025

Isosävi, J. (2020). Cultural outsiders' reported adherence to Finnish and French politeness norms. Journal of Pragmatics, 155, 177-192. https://doi.org/10.1016/j.pragma.2019.10.015

Kádár, D., \& Haugh, M. (2013). Understanding Politeness. Cambridge: Cambridge University Press. doi:10.1017/CBO9781139382717

Kecskes, I. (2015). Intercultural impoliteness. Journal of Pragmatics, 86, 43.

Leech, G. (1983). Principles of pragmatics. London: Longman.

Leech, G. (2007). Politeness: is there an East-West divide? Journal of Politeness Research,3(2), 167-206. DOI: 10.1515/PR.2007.009

Leech, G. N. (2014). The pragmatics of politeness. New York: Oxford University Press.

Liu, S., Volčič Zala, \& Gallois, C. (2019). Introducing intercultural communication: global cultures and contexts. Los Angeles: SAGE.

LoCastro, V. (2012). Pragmatics for language educators: a sociolinguistic perspective. New York:Routledge.

Lu, B.Y. (2015). Qian xi duiwai hanyu zhong de limao yongyu jiaoxue.[An overview of teaching Chinese linguistic politeness]. 15http://xuewen.cnki.net/CMFD-1013141131.nh.html (Accessed 2-1-2019)

Lu, Y. (2017). Teaching and learning Chinese in higher education: Theoretical and practical issues. London: Routledge.

Mao, L. (1994). Beyond politeness theory: "face" revisited and renewed. Journal of Pragmatics 21, 451-486

Matsumoto, Y. (1989). Politeness and conversational universals - observations from Japanese. Multilingua- Journal of Cross-Cultural and Interlanguage Communication, 8 (2-3), 207-222. doi: 10.1515/mult.1989.8.2-.207

Meier, A. J. (1997). Teaching the universals of politeness. ELT Journal, 51(1), 21-28.doi:10.1093/elt/51.1.21

Mills, S. (2003). Gender and Politeness. doi: 10.1017/cbo9780511615238

Mills, S. (2017). English politeness and class. Cambridge: Cambridge University Press.

Morgan, A-M., Spada, N., Orton, J., Tedesco, L, East, M., Scrimgeour, A., \& Hajek, J. (2018). 21 Keys ideas for languages learning in the 21st Century. Babel, 52(2), 7-14.

Nijakowska, J. (2013). Communicating solidarity with the reader: Linguistic politeness strategies in EFL Methodology Textbooks. Second Language Learning and Teaching Classroom-Oriented Research, 139- 52. doi: 10.1007/978-3319-00188-3_9

Ogiermann, E. (2009). On Apologizing in Negative and Positive Politeness Cultures. Amsterdam: John Benjamins Publishing Company.

O'Keeffe, A., Clancy, B., \& Adolphs, S. (2011). Introducing pragmatics in use. Retrieved from https://ebookcentralproquest-com.ezproxy.une.edu.au

Orton, J. (2016). Building Chinese language capacity in Australia. Retrieved May 5, 2018, From http://www. bing.com/cr?IG=3534A81BF7FC4127AE4800881C284CF4\&CID=3D497CF710026D1524F3771111AD6C17\&rd=1 \&h=iEi8onnT_BaifZ6hLrInUNtsB08E9NxEY32H6HKhQ\&v=1\&r=http://artsonline.monash.edu.au/mcjle/files/2016/ 05/ACRI-Jane- Orton-Chinese-Langauge-Capacity_web1-copy.pdf\&p= DevEx.LB.1,5066.1

Pan, Y. (1997). You are my friend: Code-switching in Chinese service encounters. In: Paper presented at the Annual Meeting of American Association of Applied Linguistics, Orlando, FL.

Pan, Y. (2000a). Politeness in Chinese face-to-face Interactions. Ablex, Stamford.

Pan, Y. (2000b). Facework in Chinese service encounters. Journal of Asian Pacific Communication 10, $25-61$.

Pan, Y., \& Kadar, Daniel, Z. (2012). Historical vs. contemporary Chinese linguistic politeness. (Report). Journal of Pragmatics, 43(6), 1525.

Pichastor, S.M. (1996, January 01). Politeness and textbooks: How to approach the teaching of communicative competence in a second language. Retrieved April 18, 2018, from http://repositori.uji. es/xmlui/handle/10234/80410

Pizziconi, B. (2015). 5. Teaching and learning (im)politeness: A look at the CEFR and pedagogical research. Teaching and Learning (Im)Politeness. doi:10.1515/9781501501654-006

Purwanto, S. \& Liliek Soepriatmadji. (2013). Politeness strategies in model conversations in English Textbooks for Elementary School Students. Parole: Journal of Linguistics and Education, 3(1 April), 75-84.

Ramos-González, N. M., \& Rico-Martín, A. M. (2015). The Teaching of Politeness in the Spanish-as-a-foreign-language (SFL) Classroom. Procedia - Social and Behavioral Sciences, 178, 196-200. doi: 10.1016/j.sbspro.2015.03.180

Savić, M. (2014). Politeness through the Prism Of Requests, Apologies and Refusals: A Case of Advanced Serbian EFL Learners. Newcastle upon Tyne: Cambridge Scholars Publishing. 
Savic, M. (2018). Lecturer perceptions of im/politeness and in/appropriateness in student email requests: A Norwegian perspective. Journal of Pragmatics. 124. 52-72. 10.1016/j.pragma.2017.12.005.

School Curriculum and Standards Authority (SCSA). (2018). Intercultural understanding - K-10 Outline. Retrieved October 29, 2018, from https://k10outline.scsa.wa.edu.au/__data/assets/ pdf_file/0004/5269/Intercultural-understanding.pdf

School Curriculum and Standards Authority (SCSA). (2017). K-10 Outline. Chinese: Second Language. Retrieved from https://k10outline.scsa.wa.edu.au/home/teaching/curriculum-browser/languages/chinese.

Senowarsito. S. (2013). Politeness Strategies in Teacher-Student Interaction in an EFL Classroom Context. TEFLIN Journal: A Publication on the Teaching and Learning of English, 24(1), 82-96.

Shih, Y. (1999). Conversational politeness and foreign language teaching. Taipei: Crane Publishing Co.

Sperber, D., \& Wilson, D. (1986, 1995, 2011). Relevance: communication and cognition (3rd ed.). Malden: Blackwell Publishing.

Stîngu, M. M. (2012). Reflexive practice in teacher education: facts and trends. Procedia - Social and Behavioral Sciences, 33, 617-621. doi: 10.1016/j.sbspro.2012.01.195

Tracy, K., \& Tracy, S. J. (1998). Rudeness at 911 Reconceptualizing Face and Face Attack. Human Communication Research, 25(2), 225-251. doi: 10.1111/j.1468-2958.1998.tb00444.x

Yan, C. (2016). A contrastive pragmatic study of politeness strategies in disagreement between native speakers of English and Chinese EFL learners. Chinese Journal of Applied Linguistics, 39(2), 231-248.

Yoon, \& Brown. (2018). A Multiliteracies approach to teaching Korean multimodal (Im)politeness. The Korean Language in America, 21(2), 154. doi: 10.5325/korelangamer.21.2.0154

Yum, J. O. (1988). The impact of Confucianism on interpersonal relationships and communication patterns in East Asia. Communication monographs, 55(4), 374-388. doi: 10.1080/03637758809376178

Zarobe, L. R. de, \& Zarobe, Y. R. de. (2012). Speech Acts and Politeness across Languages and Cultures. Bern: Peter Lang. 